\title{
BIMBINGAN SOSIAL ANAK USIA DINI BERBASIS BUDAYA LOKAL
}

\author{
Entang Kartika ${ }^{1}$ \\ Nenden Ineu Herawati ${ }^{2}$ \\ Ulfah $^{3}$
}

\begin{abstract}
ABSTRAK
Manusia bukan hanya sebagai makhluk individu tetapi makhluk sosial, karena itu, setiap manusia akan selalu berhubungan dengan orang lain dan tidak mungkin hidup sendiri tanpa bantuan orang lain. Fakta ini memberikan kesadaran bahwa untuk memenuhi kebutuhan kehidupannya individu harus melakukan interaksi sosial dan membentuk kehidupan berkelompok dengan individu lainnya. Saat manusia berada dalam kelompok sosialnya, manusia terikat kewajiban sosial yaitu untuk menghargai adanya orang lain, hak-hak dasar orang lain serta mentaati norma-norma yang berlaku di masyarakatnya. Dalam konsep interaksi sosial ini, Calhoun (1990) memandang bahwa hidup manusia tidak lepas dari interaksi sosial. Konsekuensi pokok dari interaksi individu dengan individu lainnya adalah sosialisasi dan proses belajar menjadi sosial. Salah satu upaya pembudayaan kemampuan sosial anak, yaitu melalui pendidikan pada anak usia dini. Dengan memberikan pendidikan yang lebih dini pada anak-anak dan dilakukan oleh guru-guru profesional yang peka terhadap perasaan anak, siap mendengarkan dan memahami perasaan anak, menggunakan bahasa yang dapat dimengerti, menegakan peraturan, menerima perbedaan di antara anak-anak, mampu mengendalikan emosi, memberi dukungan pada saat anak mengalami kesulitan merupakan modal bagi guru untuk dapat mengembangkan keterampilan sosial yang dibutuhkan anak untuk bersosialisasi dengan lingkungannya.

Kata Kunci : Anak Usia Dini, Budaya Lokal, Bimbingan Sosial
\end{abstract}

\section{A. PENDAHULUAN}

Pendidikan dan pembelajaran bagi anak usia dini (PAUD) sangat penting, karena pada usia dini sering disebut sebagai masa keemasan (the golden age). Pada usia dini merupakan awal yang tepat untuk meletakan dasar-dasar pengembangan sikap, pengetahuan dan keterampilan yang diperlukan bagi kehidupan anak, sehingga apabila pendidikan yang dilakukan tepat, maka anak usia dini akan mampu mengembangkan potensinya secara optimal dan dapat meraih kesuksesan kehidupaNnya masa depan.

Berdasarkan pernyataan di atas, sangat penting bagi pendidik anak usia dini untuk memiliki kemampuan pribadi profesional, Beaty (1996:331), mengemukakan paling tidak ada sembilan kemampuan yang harus dimiliki seorang pendidik, yaitu:

\footnotetext{
${ }^{1}$ Dosen PGPAUD UPI Kampus Cibiru

2 Dosen PGPAUD UPI Kampus Cibiru

${ }^{3}$ Dosen PGPAUD UPI Kampus Cibiru
} 
(1) sensitive to children's feeling and the quality of young thinking, (2) ready to lidsten to children to understand their feelings, (3) usesnonverbal forms of communication and adapts adult langguage to maximize communication with children, (4) protech orderliness without sacrificing spontaneity and childlike exuberance, (5) accepts children's individuality andf makes positive use of individual difference within the child's group, (6) exircises control without being threatening, (7) emotional-ly responsive, takes pleasure in children's succeses, and is supportive during times of trouble, (8) brings humor and imagination into the group, and (9) committed to maximixing the child's and family's strengths and potencials.

Peka terhadap perasaan dan kualitas anak, siap mendengarkan dan memahami perasaan, menggunakan bahasa (berkomunikasi) yang dapat dimengerti, menegakan peraturan, menerima perbedaan di antara anak-anak, mampu mengendalikan emosi, memberi dukungan pada masa-masa sulit anak, memiliki rasa humor dan memiliki komitmen untuk mengembangkan anak secara optimal, merupakan modal bagi guru untuk dapat mengembangkan sikap pengetahuan dan keterampilan (kognitif, afektif dan psikomotor) termasuk keterampilan sosial yang dibutuhkan anak untuk bersosialisasi dengan lingkungannya.

\section{B. PEMBAHASAN}

\section{Tugas-Tugas Perkembangan Anak Usia Dini}

Tugas perkembangan merupakan suatu tugas yang muncul dalam suatu periode tertentu dalam kehidupan individu. Tugas tersebut harus dikuasai dan diselesaikan oleh individu, sebab tugas perkembangan ini akan sangat mempengaruhi pencapaian perkembangan pada masa perkembangan berikutnya (Hurlock, 1980). Lebih jauh Havighurst mengemukakan bahwa jika seorang individu gagal menyelesaikan tugas perkembangan pada satu fase tertentu, maka ia akan mengalami kegagalan dalam pencapaian tugas perkembangan pada masa berikutnya. Adapun tugas-tugas perkembangan pada masa kanak-kanak, yaitu sebagai berikut.

a. Belajar keterampilan fisik yang diperlukan untuk bermain, seperti lompat jauh, lompat tinggi, mengejar, menghindari kejaran, dan seterusnya.

b. Membina sikap yang sehat (positif) terhadap dirinya sendiri sebagai seorang individu yang sedang bekembang, seperti kesadaran tentang harga diri (selfesteem) dan kemampuan diri (self efficacy).

c. Belajar bergaul dengan teman-teman sebaya sesuai dengan etika moral yang berlaku di masyarakatnya.

d. Belajar memainkan peran sebagai seorang pria (jika ia seorang pria) dan sebagai seorang wanita (jika ia seorang wanita).

e. Mengembangkan dasar-dasar keterampilan membaca, menulis, dan berhitung (matematika atau aritmatika).

f. Mengembangkan konsep-konsep yang diperlukan kehidupan sehari-hari.

g. Mengembangkan kata hati, moral dan skala nilai yang selaras dengan keyakinan dan kebudayaan yang berlaku di masyarakatnya.

h. Mengembangkan sikap objektif/lugas baik positif maupun negatif terhadap kelompok dan lembaga kemasyarakatan. 
i. Belajar mencapai kemerdekaan atau kebebasan pribadi sehingga menjadi dirinya sendiri yang independen (mandiri) dan bertanggung jawab.

j. Belajar keterampilan fisik yang diperlukan untuk bermain, seperti lompat jauh, lompat tinggi, mengejar, menghindari kejaran, dan seterusnya

Adapun tugas-tugas perkembangan masa kanak-kanak menurut Triyon \& Lilienthal (Hildebrand, 1986 : 45), yaitu sebagai berikut.

a) Berkembang menjadi pribadi yang mandiri. Anak belajar untuk berkembang menjadi pribadi yang bertanggung jawab dan dapat memenuhi segala kebutuhannya sendiri sesuai dengan tingkat perkembangannya di usia taman kanak-kanak.

b) Belajar memberi, berbagi dan memperoleh kasih sayang. Pada masa taman kanak-kanak ini anak belajar untuk dapat hidup dalam lingkungan yang lebih luas yang tidak hanya terbatas pada lingkungan keluarga saja, dalam masa ini anak belajar untuk dapat saling memberi dan berbagi dan belajar memperoleh kasih sayang dari sesama dalam lingkungannya.

c) Belajar bergaul dengan anak lain. Anak belajar mengembangkan kemampuannya untuk dapat bergaul dan berinteraksi dengan anak lain dalam lingkungan di luar lingkungan keluarga.

d) Mengembangkan pengendalian diri. Pada masa ini anak belajar untuk bertingkah laku sesuai dengan tuntutan lingkungannya. Anak belajar untuk mampu mengendalikan dirinya dalam berhubungan dengan orang lain. Pada masa ini anak juga perlu menyadari bahwa apa yang dilakukannya akan menimbulkan konsekuensi yang harus dihadapinya.

e) Belajar bermacam-macam peran orang dalam masyarakat. Anak belajar bahwa dalam kehidupan bermasyarakat ada berbagai jenis pekerjaan yang dapat dilakukan yang dapat menghasilkan sesuatu yang dapat memenuhi kebutuhannya dan dapat menghasilkan jasa bagi orang lain. Contoh, seorang dokter mengobati orang sakit, guru mengajar anak-anak di kelas, pak polisi mengatur lalu lintas, dan lain sebagainya.

f) Belajar untuk mengenal tubuh masing-masing. Pada masa ini anak perlu mengetahui berbagai anggota tubuhnya, apa fungsinya dan bagaimana penggunaannya. Contoh, mulut untuk makan dan berbicara, telinga untuk mendengar, mata untuk melihat dan sebagainya.

g) Belajar menguasai keterampilan motorik halus dan kasar. Anak belajar mengkoordinasikan otot-otot yang ada pada tubuhnya, baik otot kasar maupun otot halus. Kegiatan yang memerlukan koordinasi otot kasar di antaranya berlari, melompat, menendang, menangkap bola dan sebagainya. Sedangkan kegiatan yang memerlukan koordinasi otot halus adalah pekerjaan melipat, menggambar, merangkai dan sebagainya.

h) Belajar mengenal lingkungan fisik dan mengendalikan. Pada masa ini diharapkan anak mampu mengenal benda-benda yang ada di lingkungan, dan dapat menggunakannya secara tepat. Contoh, anak belajar mengenal ciri-ciri benda berdasarkan ukuran, bentuk, dan warnanya. Selain dari itu, anak dapat membandingkan satu benda dengan benda lain berdasarkan ciri-ciri yang dimiliki benda tersebut. 
i) Belajar menguasai kata-kata baru untuk memahami anak/orang lain. Anak belajar menguasai berbagai kata-kata baru baik yang berkaitan dengan bendabenda yang ada di sekitarnya, maupun berinteraksi dengan lingkungannya. Contoh, anak dapat menyebutkan nama suatu benda, atau mengajak anak lain untuk bermain, dan sebagainya.

j) Mengembangkan perasaan positif dalam berhubungan dengan lingkungan. Pada masa ini anak belajar mengembangkan perasaan kasih sayang terhadap lingkungan sekitar, seperti pada teman sebaya, saudara, binatang kesayangan atau pada benda-benda yang dimilikinya.

\section{Anak dan Kehidupan Sosial}

Bila diperhatikan pemenuhan semua tugas perkembangan anak tidak ada satu aspek pun yang tanpa melibatkan orang lain atau bebas dari pengaruh lingkungannya. Oleh karena itu, Suherman AS, (2006) mengemukakan bahwa perkembangan manusia tidak lepas dari pengaruh lingkungan, baik secara sosial, ekonomi maupun budayanya. Sifat inherent lingkungan adalah perubahan, perubahan yang terjadi dalam lingkungan, dapat mempengaruhi perilaku bahkan gaya hidup (life style) individu yang ada di dalamnya. Aturan dan adat istiadat yang berlaku pada suatu lingkungan akan mendasari perilaku sebagian besar individu anggota lingkunganya. Begitu juga dengan lingkungan-lingkungan yang lainnya, sehingga tidak menutup kemungkinan akan ditemukan kesamaan dan perbedaan perilaku seseorang karena keragamanan lingkungannya atau budaya lingkungannya. Dalam konsep interaksi sosial ini, Calhoun (1990) memandang bahwa hidup manusia tidak lepas dari interaksi sosial. Konsekuensi pokok dari interaksi individu dengan individu lainnya adalah sosialisasi dan proses belajar menjadi sosial.

Manusia lahir sebagai individu yang bermakna tidak terbagi atau tidak terpisahkan antara jiwa dan raga. Secara biologis, manusia lahir dengan kelengkapan fisik, tidak berbeda dengan makhluk lainnya. Jiwa dan raga manusia merupakan satu kesatuan untuk melakukan aktivitas atau kegiatan. Dinamika perilaku manusia tidak semata-mata digerakkan oleh aspek jasmani tapi juga rohaninya. Manusia mengerahkan seluruh jiwa dan raganya untuk berperilaku dalam setiap aspek kehidupan.

Manusia sebagai individu merupakan pribadi yang khas dan unik dengan segala corak kepribadian termasuk kecakapan dan kemampuan yang dimilikinya. Manusia sebagai individu adalah manusia sebagai perorangan yang memiliki sifat sendiri-sendiri, memiliki perbedaan sifat, watak, keinginan, kebutuhan, dan cita-cita yang berbeda satu sama lainnya berbeda dengan individu lain yang dengan ciri khas tertentu tersebut selanjutnya individu akan berupaya merealisasikan potensi dirinya.

Sementara itu manusia sebagai individu adalah berhakikat sosial (Herimanto \& Winaro 2010: 49). Artinya individu akan senantiasa dan selalu berhubungan dengan orang lain dan tidak mungkin hidup sendiri tanpa bantuan orang lain. Fakta ini memberikan kesadaran akan 'ketidakberdayaan" individu dalam memenuhi 
kebutuhannya sendiri. Kebutuhan akan orang lain dan interaksi sosial membentuk kehidupan berkelompok pada individu.

Manusia dalam kelompok sosialnya terikat pada norma-norma sebagai hasil interaksi dari individu itu sendiri. Keterikatan pada norma termasuk juga keterikatan untuk menghargai adanya orang lain. Jika dalam dimensi individu muncul hak-hak dasar manusia maka dalam dimensi sosial ini muncul kewajiban dasar manusia. Kewajiban dasar manusia adalah menghargai hak dasar orang lain serta mentaati norma-norma yang berlaku di masyarakatnya. Dengan demikian, manusia sebagai makhluk sosial individu memiliki (a) kesadaran akan "ketidakberdayaan" manusia bila seorang diri, (b) kesadaran untuk senantiasa dan harus berinteraksi denga orang lain, (c) penghargaan akan hak-hak orang lain, (d) ketaatan terhadap norma-norma yang berlaku dalam lingkunganya. Keberadaan manusia sebagai makhluk sosial menjadikan manusia melakukan peran-peran sebagai berikut, di antaranya: (1) melakukan interaksi dengan manusia lain atau kelompok, (2) membentuk kelompok-kelompok sosial, (3) menciptakan normanorma sosial sebagai pengaturan dalam kehidupan kelompok.

\section{Upaya Pendidikan dan Bimbingan dalam Meningkatkan Kemampuan Sosial}

Perubahan-perubahan sosial yang cepat (rapid sosial changes), sebagai konsekuensi dari modernisasi, industrialisasi, kemajuan ilmu pengetahuan dan teknologi telah mempengaruhi nilai-nilai moral etika dan gaya hidup (value system and way of life). Tidak semua orang mampu menyesuaikan diri dengan perubahanperubahan sosial tersebut, kadang-kadang dapat membuat individu jatuh sakit atau mengalami gangguan penyesuaian diri (adjustment disorder) (Corsini, 1981). Perubahan-perubahan tata nilai kehidupan (psycho-social changes), antara lain dapat terlihat pada:

1. Pola hidup masyarakat yang semula sosial-religius cenderung ke arah pola kehidupan masyarakat individual, materialis dan sekuler;

2. Pola hidup yang semula sederhana dan produktif, cenderung ke arah pola hidup mewah, konsumtif, dan serba instan;

3. Struktur keluarga yang semula keluarga besar (extended family), cenderung ke arah keluarga inti (nuclear family), bahkan sampai pada keluarga tunggal (single parent family);

4. Hubungan kekeluargaan yang semula erat dan kuat, cenderung menjadi longgar dan rapuh (loose family relationship);

5. Nilai-nilai religius dan tradisional di dalam masyarakat, cenderung berubah menjadi masyarakat modern yang bercorak sekuler dan serba boleh serta toleransi berlebihan (permissive society);

6. Ambisi karier dan materi yang sebelumnya menganut azas-azas hukum dan moral serta etika, cenderung berpola tujuan menghalalkan segala cara, misalnya dengan melakukan KKN (Kolusi, Korupsi, dan Nepotisme).

Fenomena psikososial tersebut dengan segala keterkaitannya memunculkan berbagai macam permasalahan kehidupan dan pada sebagian orang dapat merupakan beban atau tekanan mental yang disebut sebagai stresor psikososial. Kita hendaknya paham dan sadar bahwa perubahan psikososial memungkinkan individu 
bebas meningkatkan pengharapan hidup, dapat menjadi sumber motivasi untuk mencapai tingkat kehidupan yang lebih baik, tetapi dapat juga menyebabkan individu tidak akan pernah merasa puas dengan apa yang telah dicapainya. Situasi kehidupan seperti itu memungkinkan manusia menjadi individu yang serakah, dan berani melakukan perilaku menyimpang, yaitu perilaku yang tidak sesuai dengan nilai-nilai yang berlaku dalam masyarakat. (Calhoun \& Acocella, 1995: 10). Rogers (Wallace, 1986), berpendapat bahwa "manusia adalah makhluk yang tidak pernah selesai". Karena itu wajar apabila manusia dipandang sebagai individu yang sedang berada dalam proses berkembang atau menjadi (becoming), yaitu berkembang ke arah kematangan atau kemandirian, serta terdapat suatu keniscayaan bahwa proses perkembangan individu tidak selalu berlangsung secara mulus, atau steril dari masalah. Sehingga proses pendidikan merupakan upaya agar proses perkembangan individu itu berjalan dalam alur yang linier, lurus, atau searah dengan potensi, harapan, dan nilai-nilai budaya yang seseorang anut.

Perkembangan manusia tidak lepas dari pengaruh lingkungan, baik fisik, psikis, maupun sosial. Sifat inherent lingkungan adalah perubahan, perubahan yang terjadi dalam lingkungan, dapat mempengaruhi gaya hidup (life style) manusia sebagai bagian dari warga masyarakat. Apabila perubahan yang terjadi itu sulit diprediksi, atau di luar jangkauan kemampuan, maka akan melahirkan diskontinuitas perkembangan perilaku individu, seperti terjadinya kemandegan (stagnasi) perkembangan, masalah-masalah pribadi, atau penyimpangan-penyimpangan perilaku. Perubahan iklim lingkungan ternyata mempengaruhi perkembangan pola perilaku atau gaya hidup sebagian manusia yang cenderung menyimpang dari kaidah-kaidah moral (akhlaq yang mulia). Pelanggaran tata tertib di jalan, maraknya geng motor, tawuran antar sekolah, antar daerah bahkan antar warga dalam suatu lingkungan wilayah, minum-minuman keras, penyalahgunaan obat-obatan terlarang, narkotika, ekstasy, putau, kriminalitas, dan pergaulan bebas, bahkan memandang manusia lain sebagai bahan untuk dianiaya dan sasarannya, merupakan contoh perilaku-perilaku yang menyimpang dari kaidah moral dan nilainilai budaya sendiri. Berkaitan dengan kehidupan ini, Tilaar (1999) mengemukakan bahwa untuk menyikapi keadaan era globalisasi diperlukan munculnya manusia yang memiliki sifat keunggulan, baik keunggulan secara individualistik maupun keunggulan partisipatoris. Keunggulan partisipatoris adalah keunggulan manusia yang mampu menggali dan mengembangkan potensinya untuk mencari jalan terbaik sehingga mampu survive dalam kemajuan dan persaingan yang semakin tajam. Bukan berarti bahwa mereka memiliki kebebasan untuk membunuh potensi manusia yang lainnya tetapi tetap harus tumbuh bersama dalam keadaan sejahtera. Mereka adalah pribadi-pribadi yang memiliki pemahaman diri yang positif, memaknai perubahan lingkungan yang ada di depannya, memilih tindakan-tindakan yang akan digunakan dalam menghadapi berbagai tantangan dan masalah kehidupan, tidak mudah tergoda dengan kesenangan sesaat, memandang masalah sebagai tantangan untuk lebih berhasil, berpikir ke depan, dan mensyukuri keberhasilan yang diperoleh (James, 1998, dalam Sukartini, 2002: 4).

Dahlan (2002: 139-145), mengemukakan bahwa dalam situasi dimana peradaban mengalami titik balik, pengembangan sumber daya manusia hendaknya 
bertumpu pada keunggulan akhlak dan moral bangsa. Jika pada bidang akhlak dan moral ini cukup berhasil, maka dalam mengembangkan keunggulan di bidang lainnya tidak akan begitu sulit. Sebagai pribadi dan makhluk sosial mengisyaratkan pembelajaran tidak hanya terfokus kepada empat hal, yaitu learning to know, learning to do, learning to live together dan learning to be, sebagaimana pilar pendidikan yang dikemas badan pendidikan dan kebudayaan PBB (UNESCO, 1996), tetapi individu juga dituntut untuk belajar bagaimana belajar dilakukan (learning how to learn). Dalam konteks yang terakhir itu (learning how to learn), nilai-nilai budaya lokal dan moral sebagai landasan kehidupan diharapkan memberikan warna positif bagi perilaku belajar dan kehidupan manusia pada umumnya.

Selanjutnya, Beaty (1996:227) mengemukakan peran guru dalam peningkatan kemampuan sosial anak, yaitu: (1) Menyediakan kesempatan bagi anak-anak untuk beraktivitas dan bermain bersama, (2) Membantu anak-anak belajar ikut serta dalam permainan, dan (3) Menyediakan pengalaman yang membantu anak-anak untuk menghargai kepentinganorang lain dengan berbagi dan bergantian.

\section{Menyediakan kesempatan bagi anak-anak untuk beraktivitas dan bermain bersama}

Kemampuan untuk bergabung dalam permainan kelompok, ikut serta bermain peran, berbagi dan bergantian, juga mengatasi masalah mereka sendiri merupakan kemampuan sosial yang tidak "diajarkan" oleh guru melainkan harus melalui keterlibatan dalam permainan. Tugas guru adalah mengatur situasi agar anak dapat bermain bersama dan mengamati perkembangan keterampilan sosial anak. Anak bukan dipaksa mengikuti semua kegiatan itu tetapi garu harus menjadi fasilitator sehingga anak dapat melatih kemampuannya sendiri melalui pengalamannya selama mereka bermain. Beberapa permainan yang dapat melatih kemamapuan sosial anak, diantaranya:

\section{a) Bermain Peran}

Bermain peran merupakan kesempatan yang paling efektif untuk belajar dan melatih kemampuan sosial. Bermain peran dapat menjadi jalan untuk memahami orang-orang dan lingkungan yang ada di sekitar anak. Bermain peran atau permainan drama dapat memberikan pijakan pengalaman mempelajari bagaimana anak harus berbagi, pengambilan pilihan peran, dan menyesuaikan diri dengan kelompok dan untuk menyelesaikan konflik tanpa campur tangan orang dewasa. Selain mengajarkan kemampuan sosial, bermain peran memungkinkan anak memiliki kesempatan untuk mencoba berperan menjadi figur-figur nyata yang ada di sekeliling mereka. Dengan bermain peran, anak dapat memahami bagaimana rasanya menjadi ibu, bapak atau saudara laki-laki atau perempuan. Lebih jauh dengan bermain peran dapat membantu kejelasan bagi anak tentang konsep masyarakat dan lingkungan yang ada di sekitar mereka.

Untuk bermain peran atau permainan drama diperlukan sarana dan prasarana yang dapat membantu anak untuk membangun imajinasi. Area-area super market, toko sepatu, kantor pos dan lain-lain akan lebih efektif setelah anak terlebih dahulu mengunjungi tempat yang sebenarnya. Dalam bermain peran, tugas guru 
yaitu mencatat anak mana yang mampu mengambil suatu peran, anak mana yang tidak berperan, apakah mereka sabar menunggu giliran atau mengatasi konflik, siapakah yang berperan menjadi pemimpin dan siapakah yang menjadi pengikut. Apabila terjadi kesalahan peran maka tugas guru tidak segera menyalahkan anak, cukup kesalahan itu dicatat, dan lain waktu mereka diberikan pemahaman yang dapat membuat wawasan mereka bertambah.

\section{b) Membangun balok}

Permainan membangun balok dapat pula menjadi sarana bagi anak untuk mengembangkan permainan peran mereka. Anak bermain bangun-bangun yang mereka buat dengan menggunakan perpaduan imajinasi dan pemikiran realistis berdasarkan pengalaman hidup mereka.Ketika permainan ini berlangsung mungkin anak akan bermain sendiri dengan balok-baloknya (solitary), berdampingan dengan anak yang lain tetapi tetap sendiri-sendiri dan ada pula yang membangun kelompok secara bersama-sama. Pada saat ada anak yang mengalami kesulitan bermain balok maka usahakan kita mengajak mereka untuk mulai bermain balok.

\section{c) Membantu anak-anak belajar ikut serta dalam permainan}

Anak-anak secara umum jarang bertahan pada suatu perminan secara terus menerus, karena anak usia 3-5 tahun memiliki kemampuan memusatkan perhatian yang rendah. Dalam kondisi ini, seorang anak biasanmya meninggalkan permainan pertama dan masuk pada kelompok permainan berikutnya. Akibatnya belum tentu anak dapat diterima oleh kelompok barunya, guru hendaknya memberikan saran dan memotivasi anak untuk diterima pada kelompok lain, seandainya yang bersangkutan bosan dengan kelompok sebelumnya.

\section{d) Menyediakan pengalaman yang membantu anak-anak untuk menghargai kepentingan orang lain dengan berbagi dan bergantian}

Seorang yang berpusat pada diri sendiri, apakah anak-anak atau orang dewasa, memiliki kesulitan yang besar dalam melihat sesuatu dalam perspektif orang lain. Oleh karena itu, seorang anak usia dini yang masih egosentris kadang kadang tidak menghargai orang lain. Kemampuan sosial seperti berbagi, bergantian dan menunggu giliran belum menjadi bagian perilaku anak usia dini. Dalam kondisi ini guru dapat memberikan contoh perilaku bergantian dengan peralatan permainan seperti boneka atau buku bacaan yang menyajikan tema perilaku bergantian dan berbagi.

Ketika kemampuan sosial terinternalisasi dengan baik melalui pengalaman yang diperoleh anak di dalam kelas, perilaku mereka juga akan berubah dari egosentris menjadi kerja sama dan menghargai hak teman sepermainan mereka. Karena itu anak anak harus diberikan kesempatan mengetahui bahwa guru akan menghargai hak setiap anak dan membantu akan mempertahankan hak mereka masing-masing. 


\section{SIMPULAN}

Penguasaan kemampuan sosial bagi anak sama pentingnya dengan penguasaan kemampuan intelektual, spiritual dan sebagainya. Oleh Karena itu, penguasaan kemampuan sosial bagi anak tidak dapat hanya diserahkan kepada anak dengan mengandalkan kemampuan anak sendiri tetapi perlu diupayakan melalui pendidikan dan bimbingan secara tepat.

Dengan pemahaman pencapaian tugas-tugas perkembangan anak, seorang pendidik tidak hanya dituntut mampu memahmi karakteristik setiap anak dalam melakukan ini dan itu tetapi lebih jauh seorang pendidik mampu menyesuaikan strategi interaksi guru-anak yang mendorong pencapaian kemampuan sosial secara optimal.

\section{DAFTAR PUSTAKA}

Beaty. Janice J. (1996). Skill for Preschool Teachers, Ohio: Merril, an Imprint of Prentice Hall.

James. F. Calhoun \& James Jennifer. (1990). Thinking in the Future Tense. Terjemahan. Jakarta:PT Gramedia Pustaka Utama.

Corsini, Raymond. J. (1996). Handbook of Innovative Psychotherapies. Canada: John Wiley and Sons, Inc.

Dahlan, M. D. (2002). Warna Arah Bimbingan dan Konseling Alternatif di Era Globalisasi. Bandung: ABKIN-PPB FIP UPI.

Herimanto, \& Winarno. Ilmu Sosial dan Budaya Dasar. (2010). Jakarta: Bumi Aksara.

Hurlock, E.B. (1980). Developmental Psichology: A Life Span Approach (Fifth Eddition) Alih Bahasa (1997). Jakarta: Erlangga

Suherman,AS. Uman. (b). (2006), Pendekatan Konseling Qur'ani Untuk Mengembangkan Keterampilan Hubungan Sosial, Disertasi, Bandung: Sekolah Pascasarjana Universitas Pendidikan Indonesia.

Sunarto \& Hartono, B. Agung. (1995). Perkembangan peserta didik. Jakarta: Rineka Cipta Wahjosumidjo.

Sukartini, SP. (2005). Model Konseling Keterampilan Hidup untuk Mengembangkan Karakteristik Pribadi yang Tegar. Disertasi. Bandung: PPS UPI

Tilaar, H.A. R (1999). Beberapa Agenda Reformasi Pendidikan Nasional. Magelang: Tera Indonesia

Wallace, William A. (1986). Theory of Counseling and Psychotherapy. New York: Allyn and Boston, Inc.

Wen Sayling. (2003). Future of Education, Alih Bahasa Drs. Arvin Saputra. Batam: Luchy Publisher.

UNESCO. (1996). Treasure Within: Report to UNESCO of the Internation for the Twenty-First Century, UNESCO Publishing 